\author{
Юрій Долинний, кандидат педагогічних наук, дочент, \\ докторант кафедри педагогіки і методики технологічної освіти \\ Глухівського національного педагогічного університету імені О. Довженка
}

\title{
ОРГАНІЗАЦІЯ ТА МЕТОДИКА ПРОВЕДЕННЯ ЕКСПЕРИМЕНТАЛЬНОЇ РОБОТИ ПІДГОТОВКИ МАЙБУТНІХ ФАХІВЦІВ 3 ФІЗИЧНОГО ВИХОВАННЯ І СПОРТУ ДО РЕАБІЛІТАЦІЙНОЇ РОБОТИ 3 ДІТЬМИ 3 ОБМЕЖЕНИМИ ФІЗИЧНИМИ МОЖЛИВОСТЯМИ
}

У статті розглядається зміст організаиії та методики проведення експериментальної роботи підготовки майбутніх фахівців з фізичного виховання і спорту до реабілітаційної роботи з дітьми з обмеженими фізичними можливостями. При виріменні завдань дослідження реалізації практичноі складової системи професійної підготовки фахівців з фізичного виховання і спорту за спеціальністю “фізична терапія, ерготерапія" до реабілітаційної роботи з дітьми з обмеженими фізичними можливостями були застосовані теоретичні й емпіричні методи дослідження: аналіз та узагальнення наукової і методичної літератури; педагогічне анкетування, педагогічні спостереження й експеримент; математична статистика; дисперсійний аналіз.

Ключові слова: організаџія, дослідження, методика, експеримент, фахівці, фізичне виховання, реабілітація, професійна підготовка.

Лim. 10.

Yuriy Dolynniy, Ph.D.(Pedagogy), Associate Professor, Doctoral Student of the Pedagogics and Method of Technological Education Department Hlukhiv Oleksander Dovzhenko National Pedagogical University

\section{THE ORGANIZATION AND METHOD OF LEADTHROUGH OF EXPERIMENTAL WORK OF PREPARATION OF FUTURE SPECIALISTS ON PHYSICAL EDUCATION AND SPORT TO REHABILITATION WORK WITH CHILDREN WITH THE LIMITED PHYSICAL ABILITIES}

The health of population of Ukraine in the last decade has a proof tendency to worsening. In the last years the amount of children with the limited physical abilities, which during all life need state help, grows considerably.

Becoming the independent state, the democratic development of society, social policy of Ukraine, requires passing to the new type of the humanistic innovative athletic education, which is carried out on the basis of introduction of new maintenance, forms, methods of studies, upgrading professional preparation, development professionally of meaningful qualities of future specialist, on physical education and sport, that answer the requirements of modern rehabilitation work with children.

A system of preparation of future specialists on physical education and sport to rehabilitation work with children with the limited physical abilities is difficult enough, expense, however by very perspective business, as (the information of the American specialists show), one dollar, inlaid in proceeding in the health of suffering man, returns with tenfold income.

In the article, the maintenance of organization and method of lead through of experimental work is examined in preparations of future specialists on physical education and sport to rehabilitation work with children with the limited physical abilities.

The stages of pedagogical experiment are presented, the purpose of experiment to "Find out the dynamics of the practical component system of professional preparation of specialists on physical education and sport to rehabilitation work with children with the limited physical abilities is set".

At the decision of tasks of research realization of the practical component system of professional preparation of specialists on physical education and sport after specialty "physical therapy, ergotherapy" to rehabilitation work with children with the limited physical abilities the theoretical and empiric methods of research were applied: the analysis and generalization of scientific and methodical literature; pedagogical questionnaire, pedagogical supervisions and experiment; mathematical statistics; the analysis of variance.

Keywords: an organization, a research, a method, an experiment, specialists, physical education, rehabilitation, professional preparation.

остановка науково-практичної проблеми. Процес становлення нашої держави, демократичний розвиток суспільства, соціальна політика України вимагає переходу до нового типу гуманістичноінноваційної фізкультурної освіти, яка 

МАЙБУТНІХ ФАХІВЦІВ $З$ ФІЗИЧНОГО ВИХОВАННЯ І СПОРТУ ДО РЕАБІЛІТАЦІЙНОЇ РОБОТИ З ДІТЬМИ 3 ОБМЕЖЕНИМИ ФІЗИЧНИМИ МОЖЛИВОСТЯМИ

здійснюється на основі впровадження нового змісту, форм, методів навчання, підвищення якості професійної підготовки, розвитку професійно значущих якостей майбутнього фахівця 3 фізичного виховання та спорту, що відповідають вимогам сучасної реабілітаційної роботи з дітьми.

Отже, якісна професійна підготовка майбутніх фахівців фізичного виховання та спорту є актуальною проблемою сучасності.

Ця робота грунтується на міжнародних правових документах щодо захисту дітей 3 обмеженими фізичними можливостями: Конвенція ООН про права дитини, “Саламанська декларація”, “Стандартні правила забезпечення рівних можливостей для інвалідів”.

Процес становлення нашої держави, демократичний розвиток суспільства, соціальна політика України вимагає переходу до нового типу гуманістично-інноваційної фізкультурної освіти, яка здійснюється на основі впровадження нового змісту, форм, методів навчання, підвищення якості професійної підготовки, розвитку професійно значущих якостей майбутнього фахівця 3 фізичного виховання та спорту, що відповідають вимогам сучасної реабілітаційної роботи з дітьми [4].

Отже, якісна професійна підготовка майбутніх фахівців фізичного виховання та спорту $є$ актуальною проблемою сучасності.

Ця робота грунтується на міжнародних правових документах щодо захисту дітей 3 обмеженими фізичними можливостями: Конвенція ООН про права дитини, “Саламанська декларація”, “Стандартні правила забезпечення рівних можливостей для інвалідів”.

Життєвий досвід, практика фізичного виховання та спорту сприяють комплексній реалізації проблеми реабілітації дітей 3 обмеженими фізичними можливостями, освіти, виховання, формуванню позитивного морального та психофізичного клімату в суспільстві [5].

Актуальність і новизна дослідження. Життєвий досвід, практика фізичного виховання та спорту сприяють комплексній реалізації проблеми реабілітації дітей 3 обмеженими фізичними можливостями, освіти, виховання, формуванню позитивного морального та психофізичного клімату в суспільстві.

Актуальною проблемою сучасної педагогічної теорії і практики є процеси професійної підготовки майбутніх фахівців 3 фізичного виховання і спорту до реабілітаційної роботи 3 дітьми з обмеженими фізичними можливостями у вищій школі. Підвищена увага до цього питання великої кількості педагогів, психологів, соціологів зумовлена тим, що діти з обмеженими фізичними можливостями в сучасному демократичному суспільстві не мають права залишатися на узбіччі соціально-культурних процесів, системи людських взаємин і цінностей. Ці діти мають такі ж права, як і здорові: їм необхідно повноцінно навчатися, отримувати загальну освіту та в майбутньому приносити користь суспільству та державі [7].

Зв'язок теми статті $з$ важливими науковопрактичними завданнями. Тема дослідження включена до плану науково-дослідної роботи кафедри педагогіки і методики технологічної освіти Глухівського національного педагогічного університету імені Олександра Довженка.

Аналіз останніх публікацій за темою дослідження. Аспекти професійної підготовки майбутніх фахівців розглядали Ю.Д. Бойчук, О.А. Дубасенюк, М.Б. Євтух, В.І. Наумчук, В.В. Ягупов й інші. Професійнупідготовку майбугніх фахівців з фізичного виховання та спорту у своїх роботах висвітлювали Т.М. Бугеря, Л.Б. Волошко, А.М. Герцик, М.В. Дутчак, Р.П. Карпюк, Т.Ю. Круцевич, Р.В. Клопов, А.П. Конох, О.С. Куц, В.М. Платонов, С.Н. Приступа, Л.П. Сущенко, О.В. Тимошенко, Б.М. Шиян, Ю.М. Шкребтій.

Реалізацію принципу неперервності професійної підготовки майбутніх фахівців фізичного виховання та спорту досліджували С.У. Гончаренко, І.А. Зязюн, С.О. Сисоєва, В.О. Кукса, Л.П. Сущенко й інші. Проблему дітей 3 обмеженими фізичними можливостями та корекційну роботу з такими дітьми розглядали І.Д. Бех, В.І. Бондар, В.В. Засенко, Д.В. Лубовський, О.В. Гузій, О.С. Куц, Є.М. Мастюкова, Г.М. Мерсіянова, В.М. Синьов, Є.Ф. Соботович, Л.В. Фомічова, О.П. Хохліна, М.Д. Ярмаченко [1-3].

Особливості реабілітаційної роботи засобами фізичної реабілітації з людьми, що мають обмеження в розвитку, досліджували І.М. Башкін, Т.В. Бойчук, О.М. Вацеба, А.С. Вовканич, Т.В. Д'яченко, Ю.О. Ляной, О.К. Марченко, B.М. Мухін.

Особливості навчання та майбутньої життєдіяльності дітей 3 обмеженими можливостями опрацьовували І.В. Дмітрієва, В.В. Золотоверх, С.Ю. Конопляста, В.І. Ляшенко В.А. Липа, Н.О. Мирошниченко, Л.К. Одинченко, В.В. Тарасун, Д.І. Шульженко.

Мета статті. Розкрити зміст організації та методику проведення експериментальної роботи реалізації практичної складової системи професійної підготовки фахівців 3 фізичного виховання і спорту за спеціальністю “фізична терапія, ерготерапія” до реабілітаційної роботи з дітьми з обмеженими фізичними можливостями. 

МАЙБУТНІХ ФАХІВЦІВ $З$ ФІЗИЧНОГО ВИХОВАННЯ І СПОРТУ ДО РЕАБІЛІТАЦІЙНОЇ РОБОТИ З ДІТЬМИ 3 ОБМЕЖЕНИМИ ФІЗИЧНИМИ МОЖЛИВОСТЯМИ

Викладення основного матеріалу. Реалізація практичної складової системи професійної підготовки фахівців 3 фізичного виховання i спорту до реабілітаційної роботи 3 дітьми 3 обмеженими фізичними можливостями проводилась у 12 закладах вищої освіти України (Донбаський державний педагогічний університет, Кам’янець-Подільський національний університет імені Івана Огієнка, Луганський національний університет імені Тараса Шевченко, Східноукраїнський національний університет імені Володимира Даля, Полтавський національний педагогічний університет імені В.Г. Короленка, Сумський державний педагогічний університет імені А.С. Макаренко, Черкаський національний університет імені Богдана Хмельницького, Східноєвропейський національний університет імені Лесі Українки, Донбаський інститут техніки і менеджменту Міжнародного науково-технічного університету імені акад. Ю. Бугая, Чернігівський національний технологічний університет, Глухівський національний педагогічний університет імені О. Довженко, ВНЗ Університет "Україна") завдяки проведенню педагогічного експерименту. Педагогічний експеримент реалізації практичної складової системи професійної підготовки фахівців з фізичного виховання і спорту за спеціальністю “фізична терапія, ерготерапія" до реабілітаційної роботи 3 дітьми 3 обмеженими фізичними можливостями проводили для отримання нової інформації про динаміку впливу програми підготовки “Бакалавра з фізичної терапії, ерготерапії, фахівеця 3 фізичної реабілітації. Вчитель фізичної культури" на ефективність застосування й організації її у навчальному процесі студентів.

На першому етапі педагогічного експерименту встановлено мету експерименту “Виявити динаміку практичної складової системи професійної підготовки фахівців з фізичного виховання і спорту до реабілітаційної роботи 3 дітьми з обмеженими фізичними можливостями". Результати експерименту представлено у кількісній формі.

На другому етапі педагогічного експерименту:

1. (констатуючий). Здійснювали добір експериментальних груп; вимірювання показників в експериментальних групах та контрольних і порівняння їх між собою. Було проведено попереднє анкетування (2013 - 14 н.р.) яке дозволило встановити ідентичність експериментальних груп, а отримані дані використовували для подальшої розробки програми експериментальної методики.
2. (формуючий). Навчальний процес в експериментальних групах організовували 3 упровадженням “Програми підготовки фахівців 3 фізичного виховання і спорту до реабілітаційної роботи 3 дітьми 3 обмеженими фізичними можливостями”. Відмінності в досліджуваних групах залежали від умов проведення, представлених у загальній програмі підготовки фахівців даного напрямку підготовки. Заняття 3 експериментальної “Програми підготовки фахівців $з$ фізичного виховання і спорту до реабілітаційної роботи 3 дітьми 3 обмеженими фізичними можливостями” в досліджуваних групах проводили за робочим навчальним планом експериментальної програми у кількості 24 годин на тиждень. Студенти контрольних груп навчалися згідно із загальноосвітньою програмою підготовки фахівців з фізичної реабілітації закладу вищої освіти. Експеримент було побудовано на загальноприйнятих принципах і методах навчання. Для визначення динаміки освоєння експериментальної та загальної навчальної програми підготовки майбутніх бакалаврів 3 фізичної терапії, ерготерапії, фахівець з фізичної реабілітації з 2 по 4 курс (2014 - 15 н.р., 2015 16 н.р., 2016 - 17 н.р.) був взятий з робочого навчального плану середній кількісний показник навчальних годин за 3 роки навчання у кількості 2000 годин із розрахунку 22,5 години на тиждень 3 урахуванням 89 тижнів навчання за 3 роки. Визначення динаміки освоєння експериментальної та загальної навчальної програми підготовки майбутніх бакалаврів під час експерименту оцінювалось за 4 контрольними точками за весь період експериментальної роботи (3 2014 - 2017 рік). Перша контрольна точка від 0 до 500 навчальних годин; друга контрольна точка від 500 до 1000 навчальних годин; третя від 1000 до 1500 навчальних годин; четверта від 1500 до 2000 навчальних годин. Аналіз динаміки показників впливу освоєння експериментальної та загальної навчальної програми на рівень навченості бакалаврів проводився через кожних 500 навчальних занять за результатами запитань (\%) відношення мотиваційного, когнітивного, рефлексивного, професійного критеріїв готовності майбутніх фахівців з фізичного виховання і спорту до реабілітаційної роботи 3 дітьми з обмеженими фізичними можливостями.

3. (контрольний). Цей етап характеризувався встановленням динаміки навченості у студентів (експериментальних і контрольних груп), а також порівнянням їх між собою і їхнього впливу на навчальний процес. Третя стадія експерименту пов'язана з інтерпретацією отриманих даних, 
статистичною обробкою результатів вимірювання, здійсненням перевірки статистичної гіпотези дослідження. На цій стадіїздійснювали підготовку наукових публікацій.

Для вирішення завдань дослідження реалізації практичної складової системи професійної підготовки фахівців 3 фізичного виховання і спорту за спеціальністю “фізична терапія, ерготерапія” до реабілітаційної роботи з дітьми 3 обмеженими фізичними можливостями були застосовані теоретичні й емпіричні методи:

1. (аналіз та узагальнення наукової і методичної літератури). Для вирішення поставлених завдань у процесі аналізу наукової та методичної літератури було використано діалектичний метод (принцип історизму, принцип системності, принцип діалектичного протиріччя, принцип єдності якості й кількості, принцип діалектичного заперечення, принцип розвитку, принцип причинності); системний підхід, узагальнення, аналіз, синтез, індукція, дедукція.

Вивчення навчальної та методичної літератури, документальних матеріалів проводилося для визначення стану сучасної педагогічної діяльності 3 навчання у закладах вищої освіти , а також для аналізу різних суджень про певну проблему в історичному розвитку суспільства. Було проаналізовано й узагальнено літературу українських і зарубіжних авторів 3:

- дисциплін циклу загальної підготовки та фахового (професійно-практичного) циклу підготовки майбутніх фахівців з фізичного виховання і спорту за спеціальністю “фізична терапія, ерготерапія";

- “Основ фізичної реабілітації”, “Методів досліджень $з$ фізичної реабілітації”, “Основ догляду за хворими та людьми з обмеженими фізичними можливостями”, “Валеології, “Фармакологічних засобів фізичної реабілітації”, “Основ реабілітаційного масажу”, “Фізичної реабілітації людей з обмеженими фізичними можливостями”, “Вікової анатомії людини”, “Вікової фізіології людини”, “Теорії і методики фізичного виховання”, “Методики навчання основ здоров'я”, “Метрологічного контролю у фізичній реабілітації, “Оздоровчих технологій”, “Основ раціонального харчування”, “ЛФК, лікарського контролю”, “Сучасних апаратурних і технічних технологій фізичної реабілітації”, “Навчальної клінічної практики”, “Навчальної педагогічної практики”, "Виробничої клінічної практики”, “Виробничої педагогічної практики”;

- робочих навчальних планів закладів вищої освіти, які готують майбугніх фахівців з фізичного виховання і спорту до реабілітаційної роботи;
- дисертаційних робіт, наукових статей, матеріалів науково практичних конференцій.

У результаті аналізу встановлено, що за відомостями методичної літератури навчання у закладах вищої освіти за пропонованими програмами не достатньо приділяється уваги реабілітаційній роботі 3 дітьми 3 обмеженими фізичними можливостями, їх фізіологічним відхиленням, структурі та концепції підготовки майбутні фахівці з фізичного виховання і спорту за спеціальністю “фізична терапія, ерготерапія" до реабілітаційної роботи з дітьми з обмеженими фізичними можливостями.

Вибір експериментальної "Програми підготовки фахівців з фізичного виховання і спорту до реабілітаційної роботи $з$ дітьми $з$ обмеженими фізичними можливостями" має бути науковометодично більш насиченою та конкретно змістовною, несе суб'єктивний характер підготовки майбутніх фахівців 3 фізичного виховання і спорту до реабілітаційної роботи 3 дітьми з обмеженими фізичними можливостями.

Все це дало можливість планувати дослідницьку роботу з подальшим уточненням мети, завдань, методів експерименту, враховуючи вимоги програмного матеріалу закладів вищої освіти.

Узагальнення науково-методичної літератури дало нам можливість:

- визначити мету, об'єкт, предмет і завдання дослідження;

- вивчити методологічні підходи до процесу навчання студентів;

- визначити пріоритетний матеріал для навчання бакалаврів і магістрів.

У вивченні літературних джерел увагу приділяли науковим роботам останніх років, i ретроспективному аналізу. Загалом було вивчено 281 літературних джерел, із них 8 іноземними мовами.

2. (педагогічне анкетування, педагогічні спостереження й експеримент).

Педагогічне анкетування це найбільш поширений метод збору первинної інформації, в якому у короткий термін отримуються необхідні дані (факти поведінки, думки людей, данні про процеси і результати їх діяльності). Анкетне опитування $\epsilon$ асиметричним спілкуванням, при якому експериментатор бере на себе дійові функції, тобто суб' єкта, а респонденти виступили у якості об'єкта. Анкетне опитування це спілкування, опосередковане як особою респондента, так і технічними засобами опитування, у тому числі структурою і змістом анкети. При обробці отриманої інформації ми враховували, що дослідник підходить до предмета 


\section{ОРГАНІЗАЦІЯ ТА МЕТОДИКА ПРОВЕДЕННЯ ЕКСПЕРИМЕНТАЛЬНОӤ РОБОТИ ПІДГОТОВКИ МАЙБУТНІХ ФАХІВЦІВ З ФІЗИЧНОГО ВИХОВАННЯ І СПОРТУ ДО РЕАБІЛІТАЦЙНОӤ РОБОТИ З ДІТЬМИ 3 ОБМЕЖЕНИМИ ФІЗИЧНИМИ МОЖЛИВОСТЯМИ}

3 наукових позицій, а респондент мислить за законами буденного мислення [8].

Аналіз стану підготовки фахівців фізичної реабілітації показав, що необхідне удосконалення педагогічного процесу шляхом корекції навчальних планів i програм, науково обгрунтованої системи контролю знань, яка буде сприяти покращенню засвоєння студентами теоретичного та практичного матеріалу, а також у цілому - підвищенню якості підготовки майбутніх висококваліфікованих спеціалістів.

Достоїнства анкетування полягає утому, що воно дозволяє у порівняно короткий термін отримати багато інформації. Його дані можна піддати кількісному аналізу, звернувшись до статистичних методів, використати обчислювальну техніку.

Педагогічне спостереження проводилося для уточнення змісту, визначення особливостей організаційно-методичної роботи із студентами за спеціальністю “фізичнатерапія, ерготерапія” назаняттях 3 навчальних дисциплін циклу загальної підготовки та фахового (професійно-практичного) циклу.

Особливу увагу приділяли навчальному процесу підготовки фахівців 3 фізичного виховання і спорту до реабілітаційної роботи 3 дітьми з обмеженими фізичними можливостями 3 подальшим з'ясуванням впливу експериментальної програми підготовки бакалавра з фізичного виховання і спорту до реабілітаційної роботи 3 дітьми з обмеженими фізичними можливостями на ефективність освоєння.

3. (методи математичної статистики). Методи математичної статистики застосовувався для обробки результатів отриманих у ході дослідження. Методи математичної статистики описані у спеціальній літературі (Б.А. Суслаков (1982), В.С. Іванов (1990), Ю.М. Тюрін (1998), Н.Ш. Кремер (2000) та інші), які забезпечують кількісний і якісний аналіз.

При математичній статистиці аналізувались такі параметри: середнє арифметичне значення величини ( $\overline{\mathrm{X}})$ помилка обчислення середньої арифметичної величини (s); середнє квадратичне відхилення, яке характеризує мінливість ознаки $(\sigma)$ вірогідність різниці середніх величин (t). Оцінка вірогідності різниці статистичних показників (t) проводилась за критерієм Стьюдента. Для перевірки достовірності покращення результатів контрольних тестів значення $\mathrm{F}$ розрахункового порівнювались 3 критичними $F_{\alpha, \gamma 1, \gamma 2}$ із таблиці теоретичного розподілення Фішера для $\alpha=0,05$. За допомогою дисперсійного аналізу при кореляції даних визначили ступінь впливу різних програм. Дані оброблялись засобами статистичного пакету комп'ютерної програми Microsoft Excel 8.0 for Windows. Оцінка статистичних гіпотез виходила із 5\% рівня значимості, який забезпечує необхідну точність у педагогічних дослідженнях [2].

4. (дисперсійний аналіз). Метод дисперсійного аналізузастосовувався під час повторних вимірювань на одних і тих же об' єктах, які стикаються з сильним взаємозв'язком (кореляцією) вимірювань або випробувань. Метод дисперсійного аналізу при кореляції даних описаний Б.А.Суслаковим (1982). Основним призначенням дисперсійного аналізу є кількісне дослідження впливу зовнішніх факторів на результат експерименту.

У роботі використано сукупність загальнонаукових і наукових методів дослідження. Методологічну основу дослідження становлять роботи, які розкривають:

- загальні основи теорії й методики фізичного виховання (Л.П.Матвєєв, А.Ц.Деминский, Ж.К.Холодов, Т.Ю.Круцевич) [4];

- професійну підготовку майбутніх фахівців (Ю.Д. Бойчук, О.А. Дубасенюк, М.Б. Свтух, B.I. Наумчук, В.В. Ягупов й інші);

- професійну підготовку майбутніх фахівців 3 фізичного виховання та спорту (Т.М. Бугеря, Л.Б. Волошко, А.М. Герцик, М.В. Дутчак, Р.П. Карпюк, Т.Ю. Круцевич, Р.В. Клопов, А.П. Конох, О.С. Куц, В.М. Платонов, Є.Н. Приступа, Л.П. Сущенко, О.В. Тимошенко, Б.М. Шиян, Ю.М. Шкребтій);

- реалізацію принципу неперервності професійної підготовки майбутніх фахівців фізичного виховання та спорту (С.У. Гончаренко, І.А. Зязюн, С.О. Сисоєва, В.О. Кукса, Л.П. Сущенко й інші).

Висновки. Організація експериментальної роботи підготовки майбутніх фахівців з фізичного виховання і спорту до реабілітаційної роботи 3 дітьми з обмеженими фізичними можливостями була здійснена трьома етапами.

На першому етапі педагогічного експерименту встановлено мету експерименту. Результати експерименту представлено у кількісній формі.

На другому етапі (констатуючий) педагогічного експериментуздійснювали добір експериментальних груп; вимірювались показники в експериментальних та контрольних групах і порівняння їх між собою. На формуючому етапі проводився аналіз динаміки показників впливу освоєння експериментальної та загальної навчальної програми на рівень навченості бакалаврів проводився через кожних 500 навчальних занять за результатами запитань (\%) відношення мотиваційного, когнітивного, 


\section{ОРГАНІЗАЦІ ТА МЕТОДИКА ПРОВЕДЕННЯ ЕКСПЕРИМЕНТАЛЬНОӤ РОБОТИ ПІДГОТОВКИ МАЙБУТНІХ ФАХІВЦІВ $З$ ФІЗИЧНОГО ВИХОВАННЯ І СПОРТУ ДО РЕАБІЛІТАЦІЙНОЇ РОБОТИ 3 ДІТЬМИ 3 ОБМЕЖЕНИМИ ФІЗИЧНИМИ МОЖЛИВОСТЯМИ}

рефлексивного, професійного критеріїв готовності майбутніх фахівців.

Третій етап (контрольний) характеризувався встановленням динаміки навченості у студентів (експериментальних і контрольних груп), а також порівнянням їх між собою і їхнього впливу на навчальний процес.

При вирішенні завдань дослідження реалізації практичної складової системи професійної підготовки фахівців 3 фізичного виховання i спорту за спеціальністю “фізична терапія, ерготерапія” до реабілітаційної роботи з дітьми 3 обмеженими фізичними можливостями були застосовані теоретичні й емпіричні методи дослідження: аналіз та узагальнення наукової і методичної літератури; педагогічне анкетування, педагогічні спостереження й експеримент; математична статистика; дисперсійний аналіз.

\section{ЛІТЕРАТУРА}

1. Башкін I. Роль і місие фізичної реабілітаиії у загальній системі охорони здоров'янаселення/I. Башкін, E. Макарова, А. Кавакзе Різік // Теорія і методика фізичного виховання і спорту. - 2006. - № 3. - C. 25-29.

2. Белікова Н. О. Теоретичні і методичні засади підготовки майбутніх фахівців з фізичної реабілітаиії до здоров'язбережувальної діяльності. - Дисертація д-ра пед. наук: 13.00.04, Кабінет Міністрів України, Нач. Ун-т біоресурсів $і$ природокористування України. - К., 2012. - 450 c.

3. Гайволя, Р. Ю. До питання професійної підготовки майбутніх фахівців фізичного виховання / Р. Ю. Гайволя // Молодіжний науковий вісник: Фізичне виховання і спорт: зб. наук. пр. / Волин. нач. ун-т ім. Лесі Українки. - Луцььк, 2007. - С. 3-7.

4. Демінська Л. О. Міжпредметні зв'язки у процесі професійної підготовки майбутніх учителів фізичної культури: дис. ... канд. пед. наук: 13.00.04 / Демінська Лариса Олексіївна. - Донеиьк, 2004. $208 \mathrm{c}$.

5. Деркач А. А. Акмеологические основы развития профессионала / А. А. Деркач. - М.: Издательство Московского психолого-социального института; Воронеж: НПО МОДЭК, 2004. - 752 с. - (Серия Психологи Отечества).

6. Левченко, І.Ю. Технології навчання і виховання дітей з порушеннями опорно-рухового апарату / І.Ю. Левченко, О.Г. Приходько-М., : Академія, 2001.

7. Оржеховська В. М. Здоров'язбережувальне навчання івиховання: проблеми, поиук/В.М. Оржеховська // Наукові записки НДУ ім. М. Гоголя: Психологопедагогічні науки. - 2011. - № 4. - С. 29-31.

8. Псшкова О.В. Вступ до спеціальності (Фізична реабілітачія): [навчальний посібник] / О.В. Пєшкова. - Харків, 2007. - 147 c.

9. Попов С. Н. Физическая реабилитачия / С. Н. Попов. - Ростов н/Д.: Феникс, 2006. - 608 с.

10. Прихода I. В. Організаційно-методологічні підходи до професійної підготовки фахівичів 3 фізичної реабілітачії в Україні / I. В. Прихода // Проблеми сучасної педагогічної освіти. - 2007. Bun. 15, Y. 1. - C. $60-66$.

\section{REFERENCES}

1. Bashkin, I., Makarova, E. \& Kavakze Rizik, A. (2006). Rol i mistse fizychnoi reabilitatsii u zahalnii systemi okhorony zdorovia naselennia [The role and place of physical rehabilitation in the general system of public health care]. Theory and methods of physical education and sport, no.3, pp.25 - 29. [in Ukrainian].

2. Bielikova, N. O. (2012). Teoretychni i metodychni zasady pidhotovky maibutnikh fakhivtsiv z fizychnoi reabilitatsii do zdoroviazberezhuvalnoi diialnosti [The theoretical and methodological principles of training of future specialists in physical rehabilitation to the healthcare activities]. Doctor's thesis. Kyiv, 450 p. [in Ukrainian].

3. Haivolia, R. Yu. (2007). Do pytannia profesiinoi pidhotovky maibutnikh fakhivtsiv fizychnoho vykhovannia [To the question of professional preparation of future specialists of physical education]. Youth scientific announcer: Physical education and sport: collection of scientific lab ours of Volininskiy is a National University of the name of Lesya Ukrainian. Lutsk, pp. 3-7. [in Ukrainian].

4. Deminska, L. O. (2004). Mezhpredmetni zviazky u protsesi profesiinoi pidhotovky maibutnikh uchyteliv fizychnoi kultury [The intercourses connections in the process of training of future teachers of physical culture]. Candidate's thesis. Donetsk, 208 p.[in Ukrainian].

5. Derkach, A. A. (2004). Akmeologicheskie osnovy razvitiya professionala [Acmeological basis of professional development]. Moscov: Izdatelstvo Moskovskogo psikhologo-sotsialnogo instituta; Voronezh: NPO MODEK, 752 p. [in Russian].

6. Levchenko, I.Iu. \& Prykhodko, O.H. (2001). Tekhnolohii navchannia $i$ vykhovannia ditei $z$ porushenniamy oporno-rukhovoho aparatu [Technologies of studies and education of children are with violations of locomotorium]. Moscov: Akademiya, p. 58. [in Ukrainian].

7. Orzhekhovska, V. M. (2011). Zdoroviazberezhuvalne navchannia i vykhovannia: problemy, poshuk [Health of maintenance of studies and education: of problem, search]. Scientific messages of National State University are the name of M. Gogol. Psikhologo-pedagogical sciences, no. 4, pp. 29-31. [in Ukrainian].

8. Pieshkova, O.V. Vstup do spetsialnosti (Fizychna reabilitatsiia) [A prelude is of specialty (Physical rehabilitation)]. Kharkiv, 147 p. [in Ukrainian].

9. Popov, S. N. (2006). Fizicheskaya reabilitatsiya [Physical rehabilitation]. Rostov n/D.: Fenyks, 608 p. [in Russian].

10.Prykhoda, I. V. (2007). Orhanizatsiinometodolohichni pidkhody do profesiinoi pidhotovky fakhivtsiv $z$ fizychnoi reabilitatsii $v$ Ukraini [Organizationally-methodological going near professional preparation of specialists on a physical rehabilitation in Ukraine]. Problems of modern pedagogical education, vol. 15, part. 1, pp. $60-66$. [in Ukrainian].

Стаття надійшла до редакції 24.01.2018 